\title{
OPTIMAL TUNING OF THE TUNABLE TRANSLATIONAL-ROTATIONAL DYNAMIC ABSORBERS IN GLOBAL VIBRATION CONTROL PROBLEMS IN BEAMS
}

\begin{abstract}
The paper deals with vibration of the beam subjected to the concentrated and distributed harmonic forces, with the translational-rotational dynamic vibration absorbers attached. The linear Euler-Bernoulli beam model is assumed, the solution of the equation of motion is found with the use of Fourier method. The timeLaplace transformation allows to obtain the displacement amplitude in the frequency domain. Numerical examples present a problem of minimization of the kinetic energy of the whole or the part of the beam by optimal tuning the translational-rotational dynamic vibration absorber. The results of calculation confirm the effectiveness of using the translational-rotational dynamic absorbers in beams. In the examples studied the optimal tuning strategies minimizing the kinetic energy are determined.
\end{abstract}

Keywords: dynamic vibration absorber, beam vibration, vibration reduction, tuning, de-tuning

\section{Introduction}

Due to the application in a number of constructions, much attention has been paid to proper selection of parameters of the dynamic vibration absorbers [DVA] - mainly the most common passive tuned mass dampers [TMD] in beam structures $[1-7,10-12,15]$.

For continuous structures usually the best location of a vibration absorber is a point of application of the excitation force. If it is technically impossible or in the case of distributed loading, an important issue is the correct location of the absorber, especially in the global or non-collocated optimization problems $[1,11,13]$.

\footnotetext{
${ }^{1}$ Autor do korespondencji/corresponding author: Waldemar Łatas, Cracow University of Technology, Institute of Applied Mechanics, 31-864 Cracow, Al. Jana Pawła II 37, Poland, tel. +48 12 6283746, e-mail: latas@ mech.pk.edu.pl
} 
To improve the efficiency of vibration reduction there are used systems of tuned mass dampers [MTMD], tuned in the most general case for a single or several resonant frequencies (for broadband excitation) [8-11,13,14].

Because of the simple control algorithm it is preferable to use the tunable dynamic absorbers. The drawback of such a solution is that there may emerge the new natural frequencies of the resulting structure, depending on the position of absorbers, which coincide with the excitation frequency, so the proper location of the tunable absorbers is very important, the better performance may be also obtained by de-tuning the absorbers $[1,4,8]$.

The present paper deals with vibration of the Euler-Bernoulli beam subjected to the concentrated and distributed harmonic forces, with a system of the translational-rotational vibration absorbers attached. The aim of the study is to demonstrate the effectiveness of the rotational absorbers [3,7] and to determine the optimal tuning strategy in problems of minimizing the kinetic energy of the beam.

The rotational absorbers may significantly improve the vibration reduction because they may be effective even when placed at nodal points of the host structure, where the translational absorbers have no effect; whereas de-tuning may be advantageous by shifting the resonance frequencies beyond the excitation band $[1,4]$.

\section{Theoretical model}

A system considered in the study is shown in Figure 1. The Euler-Bernoulli beam of length $l$, mass density $\rho$, cross-section area $A$, geometrical moment of inertia $I$ and Young's modulus $E$ is subjected to the concentrated and distributed harmonic forces, the translational-rotational dynamic vibration absorbers are attached along the beam.

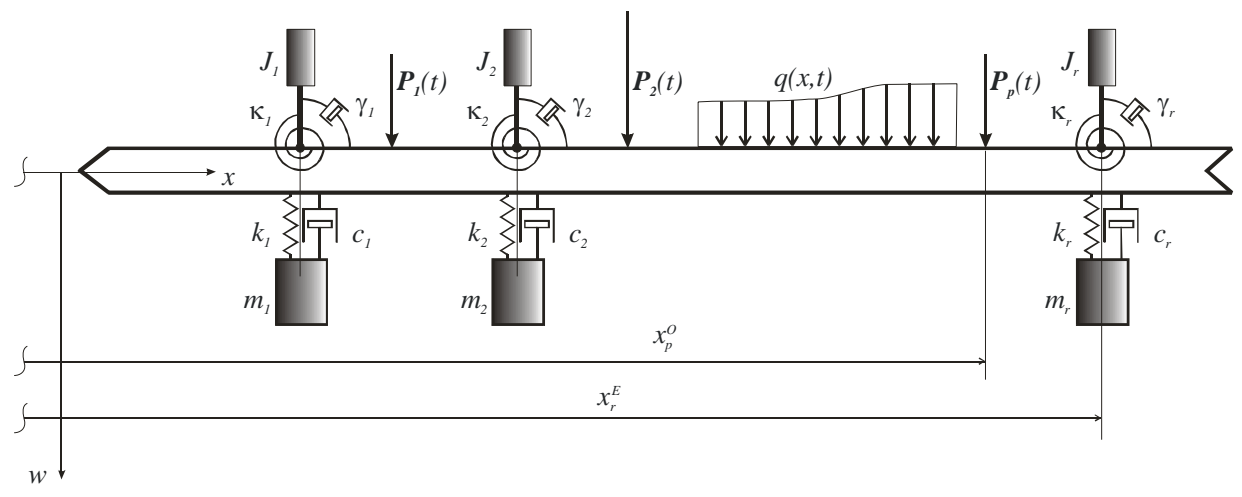

Fig. 1. Beam with a system of translational-rotational vibration absorbers

Rys. 1. Belka z układem translacyjno-rotacyjnych tłumików drgań 
Assuming small linear vibration the equation of motion takes the form [3,7]:

$$
\begin{array}{r}
\rho A \frac{\partial^{2} w}{\partial t^{2}}+E I \alpha \frac{\partial^{5} w}{\partial x^{4} \partial t}+E I \frac{\partial^{4} w}{\partial x^{4}}=q(x, t)+\sum_{j=1}^{p} P_{j}(t) \delta\left(x-x_{j}^{o}\right)+ \\
\sum_{j=1}^{r} F_{j}(t) \delta\left(x-x_{j}^{E}\right)+\sum_{j=1}^{r} \frac{\partial M_{j}(t) \delta\left(x-x_{j}^{E}\right)}{\partial x}
\end{array}
$$

where the following notations are introduced:

$q(x, t)$ - distributed force;

$P_{j}(t)-j$-th concentrated force applied at the point of coordinate $x_{j}^{o}$;

$F_{j}(t)-j$-th concentrated force applied from the translational vibration absorber at the location of coordinate $x_{j}^{E}$;

$M_{j}(t)-j$-th concentrated torque applied from the rotational vibration absorber at the location of coordinate $x_{j}^{E}$;

$m_{j}, c_{j}, k_{j}$ - mass, damping and stiffness coefficients of the $j$-th translational vibration absorber;

$J_{j}, \gamma_{j}, \kappa_{j}$ - moment of inertia, damping and stiffness coefficients of the $j$-th rotational vibration absorber;

$p$ - number of concentrated forces;

$r$ - number of translational-rotational vibration absorbers. model).

The internal damping in beam is described by parameter $\alpha$ (Voigt-Kelvin

The method of separation of variables is utilized:

$$
w(x, t)=\sum_{i=1}^{\infty} q_{i}(t) \varphi_{i}(x)
$$

The functions $\varphi_{i}(x)$ in series (2) are the eigenfunctions of the beam without absorbers attached and with the internal damping neglected. It is assumed the following form of the distributed loading: $q(x, t)=h(t) g(x)$. The functions of time $q_{i}(t)$ need to be determined.

Substitution of the series (2) into equation (1) and performing the time Laplace transformation (with zero initial conditions for beam) leads to: 


$$
\begin{array}{r}
\sum_{i=1}^{\infty}\left[\rho A s^{2} Q_{i}(s)+E I \alpha \beta_{i}^{4} s Q_{i}(s)+E I \beta_{i}^{4} Q_{i}(s)-a_{i} H(s)-\sum_{j=1}^{p} d_{j i} P_{j}(s)-\right. \\
\left.\sum_{j=1}^{r} b_{j i} F_{j}(s)-\sum_{j=1}^{r} e_{j i} M_{j}(s)\right] \varphi_{i}(x)=0
\end{array}
$$

where it is introduced: $\beta_{i}^{4}=\frac{\rho A}{E I} \omega_{i}^{2} ; \omega_{i}$ is the $i$-th natural angular frequency of the beam without vibration absorbers attached and with the internal damping neglected $(\alpha=0)$. The symbols: $Q_{i}(s), H(s), P_{j}(s), F_{j}(s), M_{j}(s)$ denote the Laplace transforms of the: $q_{i}(t), h(t), P_{j}(t), F_{j}(t), M_{j}(t)$ respectively.

Assuming that the eigenfunctions $\varphi_{i}(x)$ are orthogonal with the weight function $\eta(x)$, the numerical coefficients in equation (3) are expressed as:

$$
a_{i}=\frac{\int_{0}^{l} g(x) \varphi_{i}(x) d x}{K_{i}^{2}}, d_{j i}=\frac{\varphi_{i}\left(x_{j}^{o}\right)}{K_{i}^{2}}, b_{j i}=\frac{\varphi_{i}\left(x_{j}^{E}\right)}{K_{i}^{2}}, e_{j i}=\frac{-\varphi_{i}^{\prime}\left(x_{j}^{E}\right)}{K_{i}^{2}}
$$

where it is introduced the notation: $K_{i}^{2}=\int_{0}^{L} \eta(x) \varphi_{i}^{2}(x) d x$.

Linear independence of the eigenfunctions $\varphi_{i}(x)$ in equation (3) leads to the expression for the Laplace transform of the beam deflection and slope:

$$
\begin{aligned}
& W(x, s)=\sum_{i=1}^{\infty} \frac{a_{i} H(s)+\sum_{j=1}^{p} d_{j i} P_{j}(s)+\sum_{j=1}^{r} b_{j i} F_{j}(s)+\sum_{j=1}^{r} e_{j i} M_{j}(s)}{\rho A s^{2}+E I(1+\alpha s) \beta_{i}^{4}} \varphi_{i}(x) \\
& \frac{\partial W(x, s)}{\partial x}=\sum_{i=1}^{\infty} \frac{a_{i} H(s)+\sum_{j=1}^{p} d_{j i} P_{j}(s)+\sum_{j=1}^{r} b_{j i} F_{j}(s)+\sum_{j=1}^{r} e_{j i} M_{j}(s)}{\rho A s^{2}+E I(1+\alpha s) \beta_{i}^{4}} \varphi_{i}^{\prime}(x)
\end{aligned}
$$

Transforms of the force $F_{j}(s)$ and torque $M_{j}(s)$, applied on the beam from the $j$-th translational-rotational vibration absorber attached at the point of coordinate $x_{j}^{E}$, are given by (with zero initial conditions for absorbers) [3]: 


$$
\begin{aligned}
& F_{j}(s)=-W\left(x_{j}^{E}, s\right) \frac{\left(c_{j} s+k_{j}\right) m_{j} s^{2}}{m_{j} s^{2}+c_{j} s+k_{j}} \\
& M_{j}(s)=-\Theta\left(x_{j}^{E}, s\right) \frac{\left(\gamma_{j} s+\kappa_{j}\right) J_{j} s^{2}}{J_{j} s^{2}+\gamma_{j} s+\kappa_{j}}
\end{aligned}
$$

where it is introduced the symbol: $\Theta(x, s)=-\frac{\partial W(x, s)}{\partial x}$.

Substituting the transforms (7)-(8) into expressions (5)-(6) furnishes with the transforms of the beam deflection and slope, which should be satisfied at the points where the translational-rotational absorbers are attached to the beam, resulting in the system of $2 r$ linear algebraic equations to determine $W_{k}$ and $\Theta_{k}(k=1,2, . . r)$ :

$$
\begin{aligned}
& W_{k}\left[1+\sum_{i=1}^{\infty} D_{k i} \frac{\varphi_{i k}}{B_{i}}\right]+\sum_{j=1, j \neq k}^{r} \sum_{i=1}^{\infty} W_{j} D_{j i} \frac{\varphi_{i k}}{B_{i}}+\sum_{j=1}^{r} \sum_{i=1}^{\infty} \Theta_{j} E_{j i} \frac{\varphi_{i k}}{B_{i}}=\sum_{i=1}^{\infty} A_{i} \frac{\varphi_{i k}}{B_{i}} \\
& \Theta_{k}\left[\sum_{i=1}^{\infty} D_{k i} \frac{\varepsilon_{i k}}{B_{i}}-1\right]+\sum_{j=1, j \neq k}^{r} \sum_{i=1}^{\infty} \Theta_{j} E_{j i} \frac{\varepsilon_{i k}}{B_{i}}+\sum_{j=1}^{r} \sum_{i=1}^{\infty} W_{j} D_{j i} \frac{\varepsilon_{i k}}{B_{i}}=\sum_{i=1}^{\infty} A_{i} \frac{\varepsilon_{i k}}{B_{i}}
\end{aligned}
$$

where in order to simplify the expressions the following symbols are introduced:

$$
\begin{aligned}
& W\left(x_{j}^{E}, s\right)=W_{j}, \quad \Theta\left(x_{j}^{E}, s\right)=\Theta_{j}, \varphi_{i}\left(x_{j}^{E}\right)=\varphi_{i j}, \varphi_{i}^{\prime}\left(x_{j}^{E}\right)=\varepsilon_{i j}, \\
& a_{i} H(s)+\sum_{j=1}^{p} d_{j i} P_{j}(s)=A_{i}, \rho A s^{2}+E I(1+\alpha s) \beta_{i}^{4}=B_{i}, \\
& \frac{\left(c_{j} s+k_{j}\right) m_{j} s^{2}}{m_{j} s^{2}+c_{j} s+k_{j}} b_{j i}=D_{j i}, \frac{\left(\gamma_{j} s+\kappa_{j}\right) J_{j} s^{2}}{J_{j} s^{2}+\gamma_{j} s+\kappa_{j}} e_{j i}=E_{j i}
\end{aligned}
$$

Solution of the system (9) allows to determine from formulae (7)-(8) the transforms of the forces $F_{j}(s)$ and torques $M_{j}(s)$, and further to obtain from expressions (5)-(6) the transforms of the deflection and slope of the beam. After substituting $s=j \omega(j=\sqrt{-1})$ (steady state vibration) it may be obtained the expressions for the deflection and slope of the beam in the frequency domain. 


\section{Numerical results: tunable translational-rotational vibration absorber}

Because a simple control algorithm can be used, from the practical point of view it is preferable to use the tunable absorbers. The disadvantage of this method is the possibility of occurrence of the new resonant frequencies in the resulting structure $[1,4,7]$.

A subject of the numerical calculations is a cantilever beam, excited by a uniform distributed force in the given region, with only one translationalrotational dynamic vibration absorber attached (Figure 2; translational one and rotational one are placed at the same point).

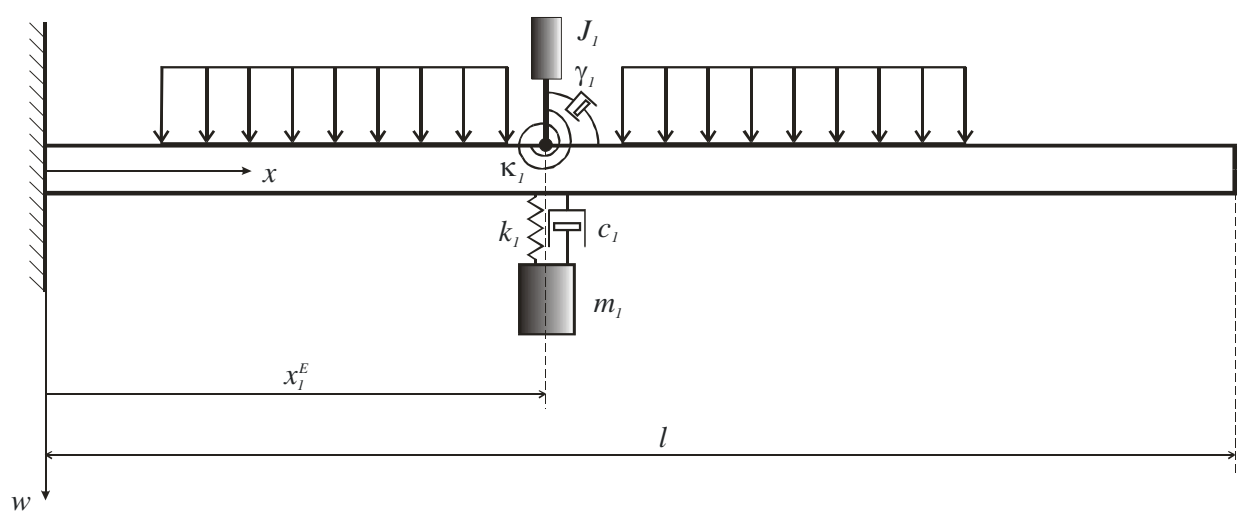

Fig. 2. Cantilever beam excited by a uniformly distributed harmonic force with a translationalrotational absorber attached

Fig. 2. Belka wspornikowa poddana harmonicznemu obciążeniu równomiernie rozłożonemu z dołączonym tłumikiem translacyjno-rotacyjnym

The beam of length $l=1.0 \mathrm{~m}$ is made of steel $\left(E=2.1 \cdot 10^{11} \mathrm{~N} / \mathrm{m}^{2}\right.$, $\left.\rho=7800 \mathrm{~kg} / \mathrm{m}^{3}\right)$, has a rectangular cross-section with a width of $b=0.05 \mathrm{~m}$, a height of $h=0.005 \mathrm{~m}$, the internal damping of the beam is neglected $(\alpha=0)$. The first four natural frequencies of the presented beam are: $f_{1}=4.19 \mathrm{~Hz}$, $f_{2}=26.26 \mathrm{~Hz}, f_{3}=73.54 \mathrm{~Hz}, f_{4}=144.11 \mathrm{~Hz}$.

The results of numerical calculations presented in sections 3.1, 3.2 relate to the problem of minimization of the kinetic energy of the whole or the part of the beam by the proper tuning of the translational-rotational vibration dynamic absorber. It is assumed in further calculations that the absorbers do not have any energy dissipating appliances $\left(c_{1}=0, \gamma_{1}=0\right)$.

Tuning of the translational-rotational absorber is described by the ratios between the natural frequencies of the translational and rotational absorbers and 
the frequency of the harmonic excitation force: $e=\frac{\omega_{T}}{\omega}, f=\frac{\omega_{R}}{\omega}$, where: $\omega_{T}=\sqrt{\frac{k_{1}}{m_{1}}}, \omega_{R}=\sqrt{\frac{\kappa_{1}}{J_{1}}}$. For $e=1.0$ and $f=1.0$ the translational and rotational absorbers are tuned to be resonant at each frequency, when $f=0.0$ it means that there is only the translational dynamic vibration absorber attached.

\subsection{Example 1 - reduction of the kinetic energy of the whole beam}

A system considered in Example 1 is shown in Figure 3 - the beam is excited by the harmonic force uniformly distributed along the whole length, the translational-rotational dynamic vibration absorber is attached at the end of the beam.

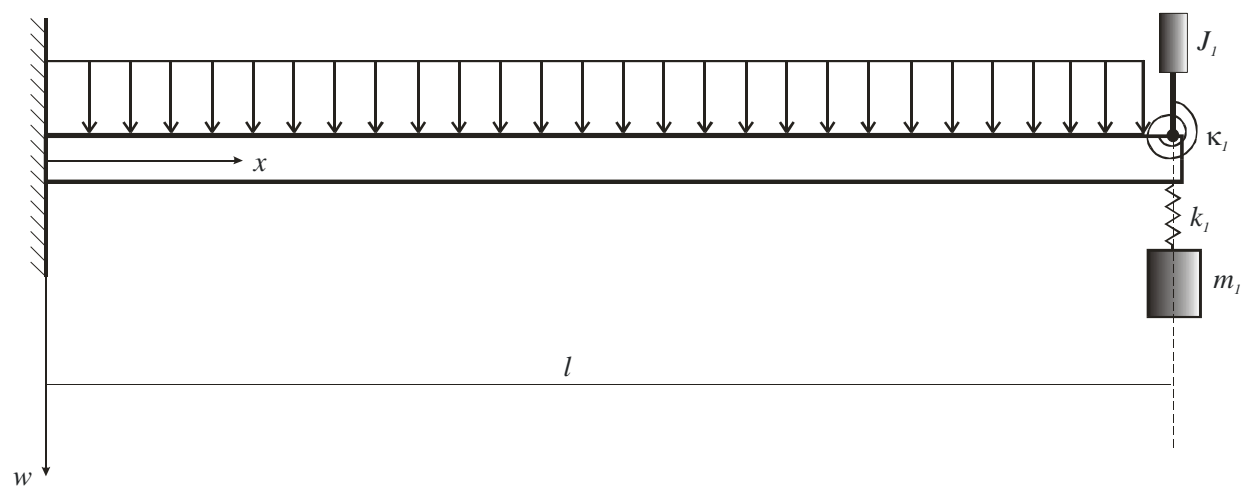

Fig. 3. Loading distribution and position of the absorber considered in Example 1

Rys. 3. Rozkład obciążenia oraz położenie tłumika rozpatrywanego w przykładzie nr 1

The task of the absorber is reduction of vibration - the aim is to determine the optimal tuning of the absorber minimizing the time-averaged kinetic energy of the whole beam, used as a global measure of vibration.

The calculated time-averaged kinetic energy is shown in Figure 4, for comparison, for three cases:

- the beam alone, without any vibration absorber attached;

- only the translational vibration absorber attached to the beam;

- the translational-rotational vibration absorber attached to the beam.

The calculations performed show that applying the translational-rotational absorber may significantly improve the effectiveness of vibration reduction when compared to the case when the translational absorber only is used.

In the example investigated the translational-rotational one $(e=1.0$, $f=1.0)$ is more effective than the translational one $(e=1.0, f=0.0)$ in band 


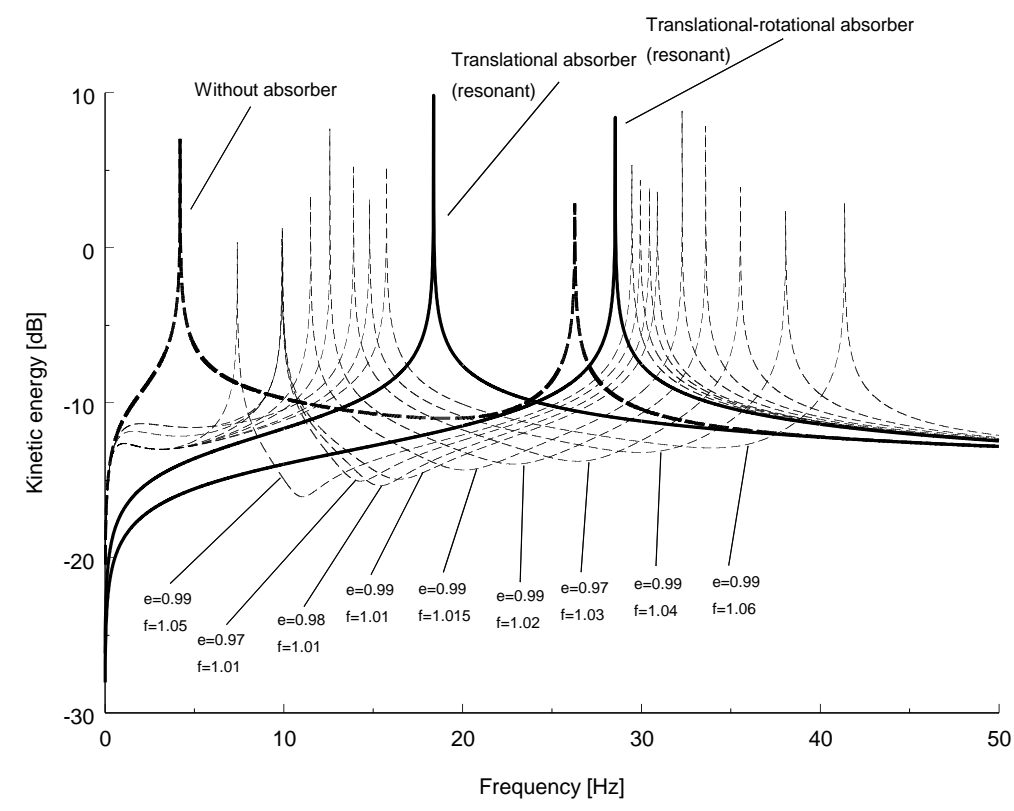

Fig. 4. Kinetic energy of the whole beam for different values of tuning parameters

Fig. 4. Energia kinetyczna całej belki przy różnych wartościach parametrów strojenia

[0.0-24.0 Hz], but there appears a new natural frequency of the structure equal $28.54 \mathrm{~Hz}$. It occurs advantegous using only the translational absorber in band [24.0-50.0 Hz].

Effectiveness of vibration reduction can be significantly improved by a slightly detuning the absorbers. The curves shown in Figure 4 are obtained for different values of the tuning parameters $e$ and $f$. It occurs beneficial slightly decreasing the value of $e$ and increasing the value of $f$.

The envelope of the obtained curves gives the minimum of the kinetic energy of the beam possible to obtain, it allows also to obtain the optimal tuning algorithm.

There is a significant improvement in vibration reduction obtained by detuning the absorber, but it is also apparent the high sensitivity of the optimal solutions to inaccurate tuning.

\subsection{Example 2 - reduction of the kinetic energy of a part of the beam}

A system considered in Example 2 is shown in Figure 5 - the beam is excited by the harmonic force uniformly distributed along half the length, the translational-rotational dynamic vibration absorber is attached in the middle of the beam. 


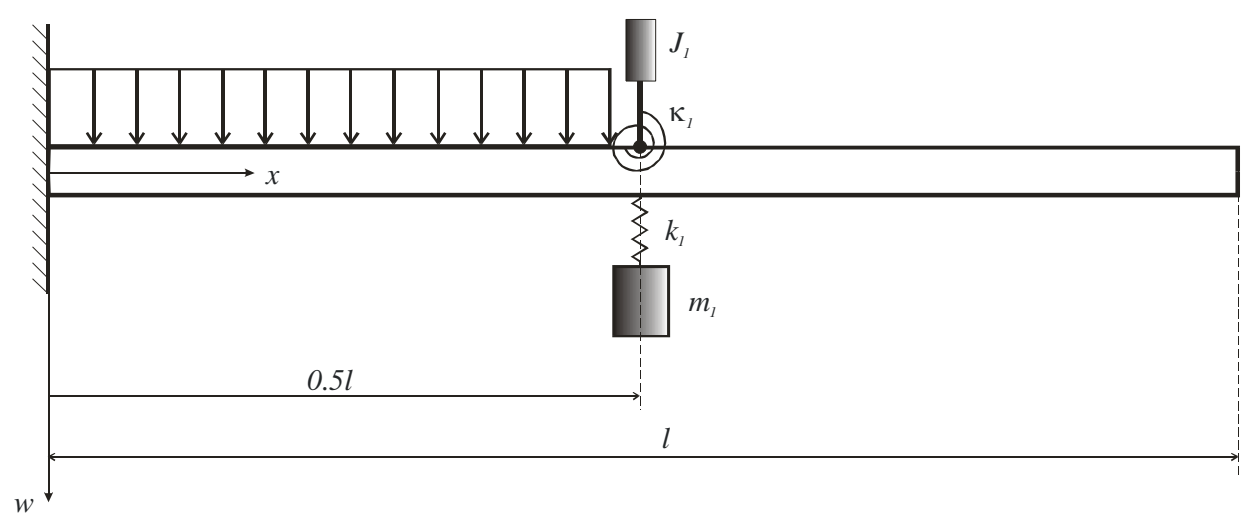

Fig. 5. Loading distribution and position of the absorber considered in Example 2

Rys. 5. Rozkład obciążenia oraz położenie tłumika rozpatrzone w przykładzie nr 2

The task of the absorber is isolation of vibration transferred from the loaded to the unloaded area of the beam - the aim is determine the optimal tuning of the absorber minimizing the time-averaged kinetic energy of the unloaded part of the beam, used as a global measure of vibration.

The calculated time-averaged kinetic energy is shown in Figure 6, for comparison, for three cases:

- the beam alone, without any vibration absorber attached;

- only the translational vibration absorber attached to the beam;

- the translational-rotational vibration absorber attached to the beam.

The calculations performed show that the best vibration reduction in bands $[0.0-16.0 \mathrm{~Hz}]$ and $[18.25-50.0 \mathrm{~Hz}]$ gives the resonant translational-rotational absorber $(e=1.0, f=1.0)$. There is a new natural frequency of the structure equal $17.11 \mathrm{~Hz}$; it occurs that the best way to eliminate the resonance is to apply only the translational absorber tuned for $e=0.98$.

The following tuning parameters describe the optimal vibration control strategy:

- band $[0.0-16.0 \mathrm{~Hz}] \quad-(e=1.0, f=1.0)$

- band [16.0-18.25 Hz] $\quad-(e=0.98, f=0.0)$

- band [18.25-50.0 Hz] $\quad-(e=1.0, f=1.0)$

Comparing to the example discussed in section 3.1, slightly detuning the translational-vibrational absorber in the vicinity of values $e=1.0, f=1.0$ does not improve here the effectiveness of vibration reduction.

If using only the translational absorber, the optimal values of the tuning parameters would be as follows: 


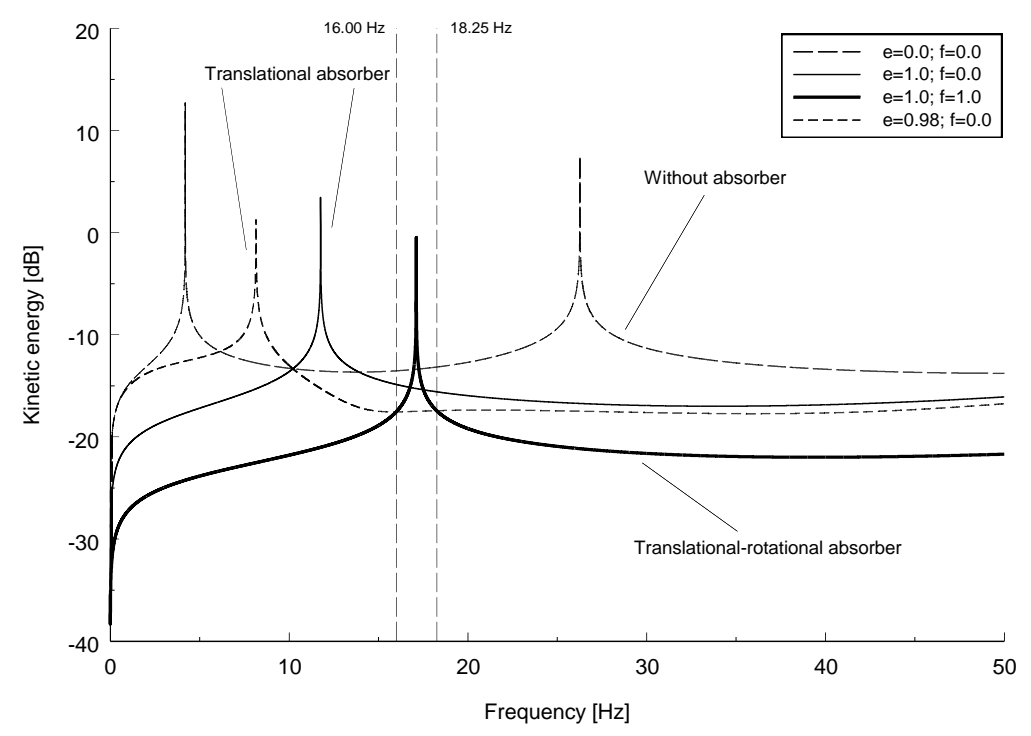

Fig. 6. Kinetic energy of the unloaded part of the beam for different values of tuning parameter

Rys. 6. Energia kinetyczna nieobciążonej części belki dla różnych wartości parametrów strojenia

- band $[0.0-10.25 \mathrm{~Hz}] \quad-(e=1.0)$

- band $[10.25-50.0 \mathrm{~Hz}] \quad-(e=0.98)$

Although there is a significant improvement in vibration reduction, which can be obtained by detuning the absorber, it is visible also the high sensitivity of the optimal solutions to inaccurate tuning.

\section{Conclusions}

It can be seen from the results of calculations presented in sections 3.1, 3.2 that there may be obtained much improvement in vibration reduction efficiency when the rotational absorbers are added to the translational ones.

Translational absorbers have no effect when are placed at nodal points of the host structure, but the rotational ones may be the most effective when located at these points. Translational and rotational absorbers applied together may be very efficient, because they can absorb and isolate both the translational and rotational motion of the beam.

In the numerical examples shown in the paper only one rotationaltranslational absorber is applied, but of course vibration reduction can be improved by applying, if it is admissible, several absorbers in different locations.

Additional resonances which occur after applying the tunable absorbers depend on their location. In the examples presented the position of the absorbers is 
fixed, but if it would be changed, it could be possible to shift the resonances beyond the excitation band $[1,4]$.

The proper tuning of the absorbers can greatly improve the efficiency of vibration attenuation, but the theoretically calculated minimum kinetic energy of the system may be difficult to obtain in practice. This is due to high sensitivity to inaccurate tuning and location. Adding damping to the absorbers can be useful. If it would be admissible, the appropriately tuned absorbers with distributed parameters may be also the option.

The computational model presented can be used in local and global problems of optimal choice of position and parameters of the system of translationalrotational vibration absorbers in beams.

\section{References}

[1] Brennan M.J., Dayou J., Global control of vibration using a tunable vibration neutralizer, Journal of Sound and Vibration, vol. 232, no. 3, 2000, pp. 585-600.

[2] Caetano E., Cunha Á., Magalhães F., Moutinho C., Studies for controlling human-induced vibration of the Pedro e Inês footbridge, Portugal. Part 2: Implementation of tuned mass dampers, Engineering Structures, vol. 32, 2010, pp. 1082-1091.

[3] Cheung Y.L., Wong W.O., Isolation of bending vibration in a beam structure with a translational vibration absorber and a rotational vibration absorber, Journal of Vibration and Control, vol. 14, no. 8, 2008, pp. 12311246.

[4] Dayou J., Brennan M.J., Global control of structural vibration using multipletuned tunable vibration neutralizers, Journal of Sound and Vibration, vol. 258, no. 2, 2002, pp. 345-357.

[5] Esmalizadeh E., Jalili N., Optimal design of vibration absorbers for structurally damped Timoshenko beams, ASME Journal of Vibration and Acoustics, vol. 120, 1998, pp. 833-841.

[6] Łatas W., Martynowicz P., Modeling of vibration of wind turbine towernacelle system with dynamic absorber (in Polish), Modelowanie Inżynierskie, vol. 44, no. 13, 2012, pp. 187-198.

[7] Łatas W., Multiple tuned tunable translational-rotational vibration absorbers in beam, Vibrations in Physical Systems, vol. 26, 2014, pp. 145-152.

[8] Li H.N., Ni X.L., Optimization of non-uniformly distributed multiple tuned mass damper, Journal of Sound and Vibration, vol. 308, 2007, pp. 80-97.

[9] Li J., Su M., Fan L., Vibration control of railway bridges under high-speed trains using multiple tuned mass dampers, ASCE Journal of Bridge Engineering, vol. 10, no. 3, 2005, pp. 312-320. 
[10] Li Quan., Fan J., Nie J., Li Quanwang., Chen Y., Crowd-induced random vibration of footbridge and vibration control using multiple tuned mass dampers, Journal of Sound and Vibration, vol. 329, 2010, pp. 4068-4092.

[11] Luu M., Zabel V., Könke C., An optimization method of multi-resonant response of high-speed train bridges using TMDs, Finite Elements in Analysis and Design, vol. 53, 2012, pp. 13-2.

[12] Yang F., Sedaghati R., Vibration suppression of non-uniform curved beams under random loading using optimal tuned mass damper, Journal of Vibration and Control, vol. 15, no. 2, 2009, pp. 233-261.

[13] Yau J.D., Yang Y.B., A wideband MTMD system for reducing the dynamic response of continuous truss bridges to moving train loads, Journal of Structural Engineering, vol. 26, 2004, pp. 1795-1807.

[14] Yau J.D., Yang Y.B., Vibration reduction for cable-stayed bridges traveled by high-speed trains, Finite Elements in Analysis and Design, vol. 40, 2004, pp. 341-359.

[15] Younesian D., Esmailzadeh E., Sedaghati R., Passive vibration control of beams subjected to random excitations with peaked PSD, Journal of Vibration and Control, vol. 12, no. 9, 2006, pp. 941-953.

\title{
OPTYMALNE STROJENIE TRANSLACYJNO-ROTACYJNEGO TLUMIKA DYNAMICZNEGO W GLOBALNYCH ZAGADNIENIACH REDUKCJI DRGAŃ W BELKACH
}

\begin{abstract}
Streszczenie
Praca dotyczy drgań belki poddanej działaniu skupionych i rozłożonych sił harmonicznych, z dołączonymi translacyjno-rotacyjnymi tłumikami dynamicznymi. W obliczeniach przyjęto liniowy model belki Eulera-Bernoulliego, równanie ruchu rozwiązano przy użyciu metody Fouriera. Zastosowanie czasowej transformacji Laplace'a pozwala na wyznaczenie amplitudy drgań w funkcji częstości. Przykłady obliczeń numerycznych dotyczą zagadnień minimalizacji energii kinetycznej całej belki lub jej części poprzez odpowiednie dostrojenie translacyjno-rotacyjnego tłumika drgań. Wyniki obliczeń numerycznych potwierdzają skuteczność stosowania translacyjnorotacyjnych tłumików dynamicznych w belkach. W badanych przykładach wyznaczono optymalną strategię dostrajania tłumików minimalizującą energię kinetyczną.
\end{abstract}

Słowa kluczowe: dynamiczny tłumika drgań, drgania belki, tłumienie drgań, strojenie

DOI:10.7862/rb.2014.33

Przestano do redakcji: $30.05 .2014 \mathrm{r}$.

Przyjęto do druku: 04.09.2014 r. 